\author{
ACTA MYCOLOGICA \\ Vol. 46 (1): 109-114 \\ 2011
}

\title{
Therrya fuckelii and other fungi on stems and branches of Pinus sylvestris following lightning damage
}

\author{
HANNA KWAŚNA and PIOTR ŁAKOMY \\ Department of Forest Pathology, Poznań University of Life Science \\ Wojska Polskiego 71c, PL-60-625 Poznań, kwasna@up.poznan.pl
}

Kwaśna H., Łakomy P.: Therrya fuckelii and other fungi on stems and branches of Pinus sylvestris following lightning damage. Acta Mycol. 46 (1): 109-114, 2011.

The evidence-based hypothesis is presented that the stems and branches of Pinus sylvestris injured by lightning strikes are colonized first by Therrya fuckelii and successively by Diplodia pinea, Nectria fuckeliana, Hyaloscypha leuconica, Gremmeniella abietina and Cenangium ferruginosum. The concomitant occurrence of these usually pathogenic fungi on injured Pinus trees in Poland signals a potential for their increased significance in Europe during climatic changes.

Key words: pathogenic fungi, lightning damage, climatic changes

\section{INTRODUCTION}

Scots pine (Pinus sylvestris L.) is amongst the most common trees occurring throughout the hemiboreal forests. It is an important tree in Polish commercial forestry. It is subject to a number of damaging biotic and abiotic factors.

In the last few years, European meteorological data show a steady increase in the incidence and violence of storms and winds, accompanied by heavy rain, hail and lightning in the highlands and lowlands (Anonymous 2005). These changes increase the incidence of mechanical damage to trees and, as a consequence, susceptibility to pathogenic fungi.

The discovery of several groups of dying trees in 50-100-year-old Scots pine stands in northwest Poland in the summer of 2006, with no etiological symptoms of crown or butt and root rot pathogens, or pest infestation, prompted a closer investigation followed by morphological examination of fungi occurring on stems and branches. Here we report the results of morphological analyses of Ascomycota occurring on dying Scots pines which have been damaged by electrical bursts during thunderstorms. 


\section{MATERIALS AND METHODS}

Samples were collected from groups of dying 50-100-year-old $P$. sylvestris trees locat-

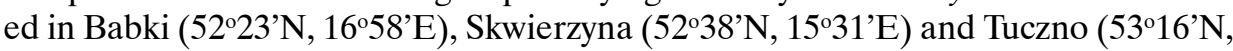
$\left.16^{\circ} 11^{\prime} \mathrm{E}\right)$ Forest Districts in northwest Poland in July 2006. Four pieces of stems (50 $\mathrm{cm}$ in length $\mathrm{x} 10-15 \mathrm{~cm}$ diam.) and ten branches with twigs $(50 \mathrm{~cm}$ in length $\mathrm{x} 0.5-$ $5 \mathrm{~cm}$ diam.) were collected from each; i.e. trees and from the litter in each focus. In total 12 stems and 30 branches from each: trees and the litter, were collected in three Forest Districts. Branches were with or without needles attached, often with yellowish-green and brittle bark, with black apothecial initials on the bark surfaces, occasionally with necrosis and bark canker. Observation of other symptoms of diseases on analysed trees continued until late November 2006.

Samples were incubated in moist chambers at $25^{\circ} \mathrm{C}$ for 8 months. Each month, fungal apothecia and pycnidia appearing on the bark surface were examined macroand microscopically; in water, in $0.1 \%$ cotton blue in water, and in Melzer's reagent ( $3 \%$ potassium iodide $+1 \%$ iodine, in water + chloral hydrate, $1: 1$, v:v). Fungi were isolated by placing non-disinfected fragments of hymenium, asci, ascospores or conidia on PDA (filtered white potatoes $40 \mathrm{~g}$, glucose $20 \mathrm{~g}$, agar $20 \mathrm{~g}$, distilled water $1 \mathrm{l}, \mathrm{pH}=7$ or $\mathrm{pH}=4$ ), MA (malt extract $30 \mathrm{~g}$, agar $15 \mathrm{~g}$, distilled water $1 \mathrm{l}$ ), MEA (malt extract $30 \mathrm{~g}$, peptone from soymeal $3 \mathrm{~g}$, agar $15 \mathrm{~g}$, distilled water $1 \mathrm{l}$ ) and SNA $\left(\mathrm{KH}_{2} \mathrm{PO}_{4} 1 \mathrm{~g}, \mathrm{KNO}_{3} 1 \mathrm{~g}, \mathrm{MgSO}_{4} \cdot 7 \mathrm{H}_{2} \mathrm{O} 0.5 \mathrm{~g}, \mathrm{KCl} 0.5 \mathrm{~g}\right.$, glucose $0.2 \mathrm{~g}$, sucrose $0.2 \mathrm{~g}$, agar $20 \mathrm{~g}$, distilled water $1 \mathrm{l}$ ). Fungi were identified on the basis of colony morphology and sporulation. The incidence of individual fungi $(\%)$ was calculated as percentage occurrence in samples examined in the laboratory. The statistical significance of differences in numbers of stems or branches colonized by particular fungal species in two locations was determined by $\chi^{2}$ test.

\section{RESULTS}

Circular, 30-50 m wide areas, each including 10-32 dying Scots pines were observed in the Babki, Skwierzyna and Tuczno Forest Districts, in northwest Poland, in early summer 2006 (Fig. 1). The affected trees had 10-50\% branches and twigs dead, still attached or gradually abscising. The whole of dead upper parts of the main stems (4-6 $\mathrm{m}$ in length) and dying branches were covered with scattered or clustered black apothecia. The bark was intact or brittle and discolored yellowish-green (Figs 2, $3)$. There were more apothecia on stems with intact bark and fewer on stems with brittle and discolored bark. Needles had been dying and falling continuously for 3-4 months from the infected but usually attached branches. The death of trees progressed and spread to trees located around the initially affected area. Adjacent trees showed first symptoms of decline within 4-5 months. Only one in 200 primarily and secondarily affected trees had an elongated, $5 \mathrm{~m}$ long wound that could have been caused by a lightning strike. 
Table 1

The percentage of Scots pine stems and branches moderately colonized by T. fuckelii invaded by secondary colonizers in Babki, Skwierzyna and Tuczno Forest Districts

\begin{tabular}{|l|c|c|c|c|c|c|}
\hline \multirow{2}{*}{ Secondary colonizer } & \multicolumn{2}{c|}{ Babki } & \multicolumn{2}{c|}{ Skwierzyna } & \multicolumn{2}{c|}{ Tuczno } \\
\cline { 2 - 7 } & Stems & Branches & Stems & Branches & Stems & Branches \\
\hline Cenangium ferruginosum Fr. & 10 & $35^{\text {ab }}$ & 10 & $15^{\mathrm{a}}$ & 10 & $10^{\mathrm{b}}$ \\
\hline Diplodia pinea (Desm.) J. Kickx f. & 40 & 50 & 50 & $35^{\mathrm{c}}$ & 40 & $60^{\mathrm{c}}$ \\
\hline Gremmeniella abietina (Lagerb.) M. Morelet & 0 & $50^{\mathrm{b}}$ & 0 & $40^{\mathrm{d}}$ & 0 & $10^{\text {bd }}$ \\
\hline Hyaloscypha leuconica Cooke) Nannf. & 0 & $10^{\mathrm{e}}$ & 0 & $5^{\mathrm{c}}$ & 0 & $0^{\text {ec }}$ \\
\hline Nectria fuckeliana C. Booth & $10^{\text {ae }}$ & $15^{\text {ab }}$ & $0^{\mathrm{a}}$ & $25^{\text {ad }}$ & $0^{\mathrm{e}}$ & $0^{\text {bd }}$ \\
\hline
\end{tabular}

Abbreviations: ${ }^{a}$ - the ratio for stems or branches in Babki and Skwierzyna is significantly different from $1: 1$ at $\mathrm{P}=0.05{ }^{\mathrm{b}}$ - the ratio for stems or branches in Babki and Tuczno is significantly different from $1: 1$ at $\mathrm{P}=0.001 ;{ }^{\mathrm{c}}$ - the ratio for stems or branches in Skwierzyna and Tuczno is significantly different from $1: 1$ at $P=0.05 ;{ }^{\mathrm{d}}-$ the ratio for stems or branches in Skwierzyna and Tuczno is significantly different from $1: 1$ at $\mathrm{P}=0.001{ }^{\mathrm{e}}-$ the ratio for stems or branches in Babki and Tuczno is significantly different from $1: 1$ at $\mathrm{P}=0.05$.

After 20 days of incubation in moist chambers, the black apothecia opened and revealed asci and ascospores typical of Therrya fuckelii (Rehm) Kujala (Minter 1996). Asci matured sequentially, were clavate, with a flat apex, (70-) 105-160 (-191) x (6.5-) $10-15(-17) \mu \mathrm{m}$. Ascospores were long, thin, vermiform to cylindrical, with delicate thread-like tips, parallel, hyaline, thin-walled, smooth, (64-) 65-110 (-157) x (2.5-) 3-4 (-4.5) $\mu \mathrm{m}$ (Figs 4-6).

The necrotic phloem and partly necrotic xylem occurred on stems colonized by $T$. fuckelii. No further fungi or pests occurred on stems and branches covered densely with T. fuckelii apothecia. Between 35-60\% of stems and branches moderately covered with $T$. fuckelii apothecia showed additional sporulation by Diplodia pinea (the 'type A' of Sphaeropsis sapinea (Fr.: Fr.) Dyko \& Sutton) (the cause of the sphaeropsis tip blight) (Tab. 1). Between $0-25 \%$ of stems and branches showed sporulation by Nectria fuckeliana (the cause of the stem canker) and Hyaloscypha leuconica (usual colonizer of the dead tissues). Between $0-50 \%$ of stems and branches from upper parts of diseased crowns showed sporulation by Gremmeniella abietina var. abietina (the 'type A' of the European race, the cause of the scleroderris canker) and Cenangium ferruginosum (the cause of the cenangium canker). The differences in number of stems or branches colonized by particular fungal species in two different locations were often statistically significant.

Sporulation by secondary invaders appeared on stems and branches in the forest and in the laboratory, 4-8 months after T. fuckelii apothecia were first noted. The 'type A' of S. sapinea was determined on the basis of size of conidia (Palmer et al. 1987). The 'type A' of the European race of G. abietina was determined on the basis of symptom expression of colonized trees in field and growth properties, production of conidia in vitro, septation of conidia (Hellgren 1995; Hellgren, Högberg 1995). Only occasional samples colonized by $D$. pinea showed symptoms of initial advanced bark necrosis. 


\section{DISCUSSION}

Therrya fuckelii was the first fungus observed on upper stems and branches of dying Scots pine trees grouped in approximately circular 30-50 m diam. foci, in three forest districts situated 100-150 km apart in northwest Poland, in 2006. Apothecia of the fungus were present along the whole length of infected branches. No other primary pathogens of Scots pine stem tops, e.g. Cronartium flaccidum (Alb. \& Schwein.) G. Winter and Endocronartium pini (Willd.) Y. Hirats. were observed.

Minter (1996) and Torp (2004) reported that T. fuckelii was commonly found on freshly killed, dead or self-pruned, $0.5-7 \mathrm{~cm}$ diam. Pinus branches and twigs, either attached to the tree (mostly in lower parts of the crown) or fallen. The bark on infected branches was brittle and discolored bright red to brown. Unlike fallen and non-colonized twigs, the stems and branches colonized by $T$. fuckelii never had needles attached. A role for T. fuckelii in self-pruning of Scots pine has been suggested (Minter 1996).

Torp (2004) found T. fuckelii in the snag tops of injured $P$. sylvestris trees in Norway, in 2003-2004. The provenance of six specimens of the fungus deposited in the Norwegian Herbarium prompted Torp (2004) to conclude that $T$. fuckelii occurs in a very specialized niche. After careful examination of the snag tops of the injured trees Torp (2004) concluded that colonization by $T$. fuckelii may have been preceded by damage from electrical bursts during thunderstorms.

The occurrence of T. fuckelii in Poland followed severe weather in 2004-2005, when the northwest part of the country had 180 days with rainfall, 20 days with thunderstorms, more than 40 days with severe frosts, relatively high humidity $(78-84 \%)$ and strong winds $\left(4 \mathrm{~m} \mathrm{~s}^{-1}\right.$ mean). Some thunderstorms were particularly severe, with strong wind, hail, flash flooding and abundant lightning. The number of electrical ground strikes in May-September peaked at 12 per km² in 2004 and 6-20 per km² in 2005 with the greatest concentration in Tuczno. Very warm weather preceded the most severe conditions, which included hail storms (Anonymous 2005).

These observations and those of Minter (1996) and Torp (2004) suggest that $T$. fuckelii may specialize in invading the freshly damaged bark. The endophytic status of T. fuckelii cannot be excluded.

Since D. pinea, N. fuckeliana, H. leuconica, G. abietina and C. ferruginosum, appeared on the affected branches in a succession, these fungi seem to be secondary invaders of stems and branches colonized primarily by T. fuckelii. As the secondary invaders did not colonize the branches strongly colonized by $T$. fuckelii, the latter fungus may act as a natural antagonist.

Diplodia pinea, N. fuckeliana, G. abietina and C. ferruginosum have been recognized as endophytes, and weak or latent pathogens of conifers, active only locally and periodically (in specific weather conditions), able to colonize stressed, weakened, injured or dying woody tissues. Currently, however, the significance of these fungi in Poland is increasing (Mańka 2005).

Diplodia pinea has emerged as a serious problem in the last 10 years (Lakomy, pers. comm.). Pathogen appears mostly in Scots pine plantations, in central and western Poland. According to Zwolinski et al. (1990) heavy damage of trees and epidemics are usually associated with several years of drought, and frosts, cold and wet 

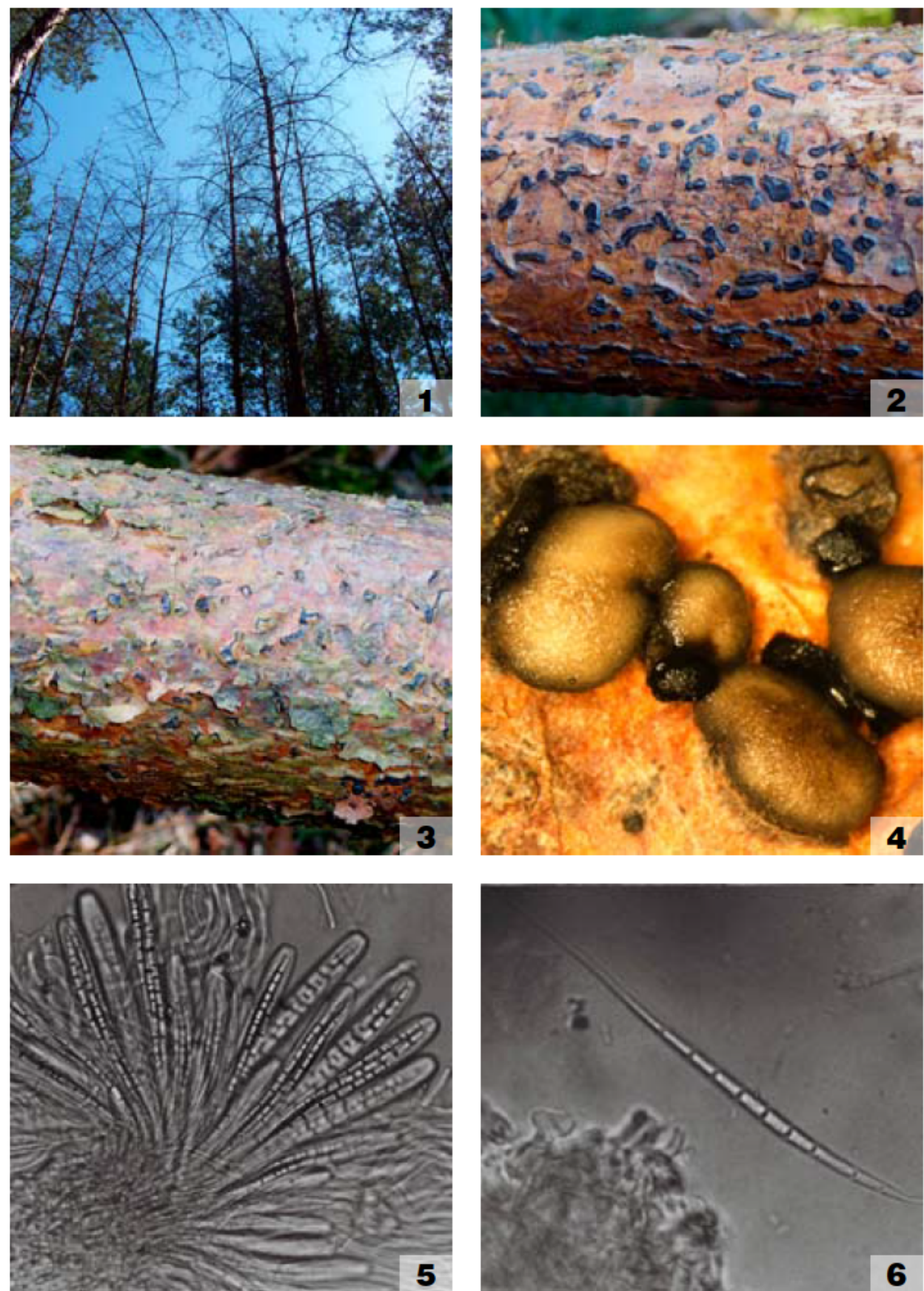

Figs 1-6. Therrya fuckelii. 1. Circular, $30-50 \mathrm{~m}$ wide area with Scots pines colonized by T. fuckelii; all needles fell three months after death of trees. 2, 3. Apothecia; more numerous on stems with intact bark (2) and less numerous on stems with brittle and discolored bark (3). 4. Final stage of apothecial development. 5. Fragment of hymenium. 6. Ascospore. Scale bars for Fig. $4=5 \mathrm{~mm}$, for Fig. $5=20 \mu \mathrm{m}$, for Fig. $6=10 \mu \mathrm{m}$. 
springs as well as hail damage. Diplodia pinea is more aggressive than D. scrobiculata J. de Wet, Slippers \& M. J. Wingf. (the 'type B' of S. sapinea).

Pathogenic activity of $N$. fuckeliana has hitherto been reported only on Abies concolor (Gord. \& Glend.) Lindl. ex Hildebr. and Picea abies (L.) H. Karst. So far, the fungus has been exceptional on Pinus. Earlier, only Crane (2005) observed $N$. fuckeliana on $P$. radiata D. Don (in South Island of New Zealand), in association with the pine fluting disease.

Gremmeniella abietina and $C$. ferruginosum periodically cause severe losses of green foliage, mostly in younger (G. abietina) Scots pine stands in Poland (Mańka 2005). It is the first report on the occurrence of these fungi in association with storm and lightning damage.

The association between $T$. fuckelii and D. pinea, N. fuckeliana, G. abietina, $C$. ferruginosum results from similar preferences for Pinus tissues and the weather and climatic conditions.

The similar association between Therrya piceae Funk and Lachnellula agassizii (Berk. \& M.A. Curtis) Dennis, Sarea difformis (Fr.) Fr., Corniculariella abietis P. Karst., Botryosphaeria piceae A. Funk and Tryblidiopsis pinastri (Pers.) P. Karst. was observed in British Columbia (Canada) on Picea glauca (Moench) Voss where the above mentioned species contributed to the perennial stem cankers (Funk 1982). Similarly to our observations, stem cankers caused serious damages to spruce but only on the localized small areas. Damages acted as indicators of unfavourable growing conditions for spruce. The mineral deficiencies in the soil were considered to be the main predisposing cause (Funk 1965).

\section{CONCLUSION}

It is hypothesized that the successive colonization and co-occurrence of $T$. fuckelii, and D. pinea, N. fuckeliana, G. abietina, C. ferruginosum on Scots pine was an ecological response to the changes caused by a physical stimulus, i.e. a lightning strike. The detection of $T$. fuckelii on the directly or indirectly injured $P$. sylvestris trees establishes environmental event and may be a powerful predictor of ecological behaviour of other fungal colonizers. The occurrence of $T$. fuckelii may signal risk from $G$. abietina, $C$. ferruginosum and $D$. pinea with no immediate production of disease in the case of latent infections. The successive colonization of injured Scots pines has significant implications for disease management. 


\section{REFERENCES}

Anonymous 2005. Bulletin of the National Hydrological and Meteorological Service. Instytut Meteorologii i Gospodarki Wodnej. Warszawa.

Crane P.E. 2005. Nectria fuckeliana disease of Pinus radiata ecology and epidemiology. Report no 38080. www. fbrc.org.nz.

Funk W. 1965. A new parasite of spruce from British Columbia. Can. J. Plant Pathol. 43: 45-48.

Funk W. 1982. Therrya canker of spruce in British Columbia. Can. J. Plant Pathol. 4: 357-361.

Hellgren M. 1995. Gremmeniella abietina - biology and genetic variation within Fennoscandia. Doctoral thesis. Swedish University of Agricultural Sciences, Department of Forest Mycology and Pathology, Uppsala, pp 1-60.

Hellgren M., Högberg N. 1995. Ecotypic variation of Gremmeniella abietina in northern Europe-Disease patterns reflected by DNA variation. Can. J. Bot. 73: 1531-1539.

Mańka K. 2005. Fitopatologia leśna. Państwowe Wydawnictwo Rolnicze i Leśne. Warszawa. pp 391.

Minter D.W. 1996. IMI descriptions of fungi and bacteria. No. 1297 Mycopathologia 136: 171-173.

Palmer M.A., Stewart E.L., Wingfield M.J. 1987. Variation among isolates of Sphaeropsis sapinea in the north central United States. Phytopathology 77: 944-948.

Torp T. B. 2004. Occurrence of Therrya fuckelii (Rehm) Kujala on Scots pines in the eastern part of Norway. Master degree thesis. Norges Landbrukshøgskole.

Zwolinski J.B., Swart W.J., Wingfield M.J. 1990. Economic impact of the post-hail outbreak of dieback induced by Sphaeropsis sapinea. Eur. J. For. Pathol. 20: 405-411.

Therrya fuckelii i inne grzyby na strzałach i gałęziach Pinus sylvestris uszkodzonych przez uderzenia pioruna

\section{Streszczenie}

Praca stara się udowodnić, że strzały i gałęzie sosny zwyczajnej uszkodzonej uderzeniami pioruna kolonizowane są przez Therrya fuckelii, a następnie przez Diplodia pinea, Nectria fuckeliana, Hyaloscypha leuconica, Gremmeniella abietina i Cenangium ferruginosum. Sukcesja i wspólne występowanie tych, w większości patogenicznych, grzybów na uszkodzonych sosnach sygnalizuje wzrost ich potencjału i znaczenia w Polsce i Europie. Wynikają one z obserwowanych ostatnio zmian klimatycznych i występowania pogody obfitującej w częste burze i wyładowania atmosferyczne. 